\title{
How do Revolting Young People Become Radicals - The Case of Slovakia
}

\author{
By Gizela Brutovská* \& Matúš Béreš ${ }^{ \pm}$
}

\begin{abstract}
Radicalisation of young people is a gradual process. Emptiness in a form of distrust has spread into all areas of human life (work, family, church, etc.) and has led to indifference and passivity. This, coupled with young person's disintegration in terms of values and norms (disintegration) and social isolation (disorganization), prompts some sort of revolt. Losing footing in many life situations, the young person resorts to expressions of anger, which, if left unresolved, gradually grows into aggression and violence. The paper aims to identify and describe the sources of anger and frustration of young radicals in Slovakia. It also outlines the most common targets of their aggression. Close attention is paid to Slovak conscripts (Slovenski branci), one of the radical groups in Slovakia. The Slovak Ministry of Defence regards this paramilitary group as a security threat. The theoretical part of the paper is based on works of sociologists who introduce the concept of indifferent society (Lipovetsky 2008) and examine barriers that hinder young people's integration (Durkheim 1973). Defining aggression and violence that originate in anger is based on Arendt's study (2004). The empirical part of the paper is a result of the qualitative research conducted among young radicals, aged 14-17 in Slovakia in a form of case studies.
\end{abstract}

Keywords: indifference, disintegration, revolt, anger, aggression

\section{Introduction}

Radicalisation of young people in Slovakia, as a social problem, did not occur overnight. It is a gradual process that has been intensified as a result of pandemic measures (young people feel restricted in their freedom of movement; they miss face-to-face classroom learning; they were forced to reduce social contacts; they are at risk of becoming unemployed, losing their part-time or full-time jobs in businesses that had to be closed; they have limited opportunities for leisure and cultural activities; they get into debt, etc.), despite the pandemic posing the smallest health risk to this age group. Social networking sites also considerably contribute to spreading of radical ideas (for example, through hyperemotional Facebook statuses and vulgar and aggressive comments). The result of the abovementioned factors is the emergence of various real-life (not just virtual) radical groups, such as Slovak conscripts.

Quantitative researches conducted by non-profit organizations among young people in Slovakia, for instance Hodnoty mladých - veria mladí v demokraciu? (Rada mládeže Slovenska 2021); Ako vidiš extrémistov Ty? (IUVENTA 2013); Pravicový extrémizmus a mládež na Slovensku (Štefančík et al. 2013) and Súčasný

*Assistant Professor, Technical University of Kosice, Slovak Republic.

${ }^{ \pm}$Assistant Professor, Technical University of Kosice, Slovak Republic. 
pravicový extrémizmus a ultranacionalizmus na Slovensku (Mesežnikov and Gyárfášová 2016) show that there is a relatively high level support for radical and even extremist solutions among young people in Slovakia.

The research conducted by the Youth Council of Slovakia (2021) revealed that in the 2020 election, $11 \%$ of young people would have voted for right-wing extremist parties and $41 \%$ would have voted for parties with a populist agenda. It is an increase of more than $10 \%$ in comparison to the previous two years. Mesežnikov and Gyárfášová (2016) list numerous factors that influence young people's attitudes towards radicalisation: problems linked to the overall development of society; loss of social security; disillusionment with the political elite; effectiveness involved in the exercise of political power and solutions to social problems offered by the mainstream political elite; prevalent value orientation patterns and types of political culture of the population (authoritarianism, paternalism, xenophobia); the use of a specific segment of social networking sites for communication, obtaining and disseminating information; promotion of "alternative" political and historical narratives, including the popular conspiracy theories; unexplained "white spots" in modern Slovak history; ideological infiltration of foreign ideas supporting views rejecting liberal democracy and the ideological legacy of the fascist wartime Slovak State and socialism. Above all, however, it is the underlying mobilizing force of ethnic nationalism and anti-Roma racism (Roma people in Slovakia represent about 8\% of the population. They are one of the most numerous national minorities. Many of them live socially and spatially excluded/in settlements/from the majority population. They are extremely poor, they live in houses without the necessary equipment, the parents of the children are without a job. In many settlements there is no source of drinking water, public lighting, no sewerage, no access road) as well as the citizens' response to the migration wave from countries with different ethnic and confessional grounds to Europe (even if Slovakia was actually not affected by this wave of migration whatsoever).

The paper outlines the process of radicalisation of young people in Slovakia and identifies its sources and forms, in both theoretical and empirical dimensions. The theoretical part of the paper analyses the individual phases of radicalisation. The first phase of radicalisation - revolt is linked to the overall character of the contemporary society (indifferent, distrustful, individualized), which, for many young people, results in a process of disintegration coupled with disorientation in terms of values and disorganization in terms of social interactions. The second phase involves transition from revolt and frustration (feeling disconcerted) to anger associated with the inability to improve (or influence) and quickly (and effectively) solve their personal problems and problems within society. The third phase is transition from anger to aggression and violence that present to these young people a way of accepting the views, attitudes, and solutions they want to achieve. One of such radical groups that show young people "the right path" is the radical group Slovenskí branci [Slovak conscripts]. The empirical part of the paper presents findings of the qualitative research, which analysed the character of a radical and non-radical teenager in Slovakia, using the life-story approach. It also attempted to identify the sources and forms of radicalisation. 


\section{Literature Review}

Research into radicalisation of young people cannot be separated from the legal, societal, social, ideological (including religious), and political contexts in which it takes place. When young people are concerned, we need to take into account their age and their family background that are both important factors determining the manner in which they find their place within society or construct their idea of life. The legal context provides a foundation for defining radicalisation as such given the possible ramifications concerning criminal proceedings, since radicalisation poses a security threat to society. To see a broader social context, it is required, among other things, to know shared values in that society, for instance, trust (in a political system and democratic system, in institutions of a democratic society, in other people, etc.), equality, justice, tolerance, solidarity, independence (self-reliance and self-confidence) and so on. The way in which wealth in society is distributed among different nationalities, ethnicities, minorities is an important indicator of the social context. The possibilities of ideological freedom (including religious freedom) and their equal status lay a foundation for the ideological context. The political context of radicalisation requires a description of activities of political parties in society.

The impetus for radicalisation in general, and for young people too, is dissatisfaction with the current (legal, social, societal, ideological and political) state of society measured against their own quality of life. Smolík (2020) analysed tension and radicalisation in post-communist countries and identified several causes:

- a division of society into the rich and the poor,

- ethnic and national differences,

- majority-minority relations,

- conflicts between political parties declaring different orientation in terms of politics, integration and security,

- different value and cultural patterns of behaviour.

Khosrokhavar $(2005$, p. 286) defines radicalisation as a process whereby, “...an individual or a group adopts and acts violently as a result of an extreme political, social, or religious ideology that challenges the prevailing social, cultural, and political order." In general, radicalisation is an attitude of subjecting existing circumstances to critical questioning and advocating the reform or abolition of those circumstances unless their existence can be justified as a matter of principle. It does not demand elimination of the democratic constitutional state as a whole, only its individual aspects. Radical demands and attitudes remain within the bounds of legal definitions, but are mostly on the verge thereof (Smolík and Vejvodová 2010).

Radicalisation is often seen as a grey zone between the democratic and the extremist. One of the pitfalls of conventional theories of radicalisation is the urge to explain the process of radicalisation using the concepts of abnormality, irrationality, or even mental or social weakness. Radicalised individuals are 
regarded as socially deviant (excluded from the social world), even pathological (ruthless, driven by mental disorders). Several research studies, e.g., Crenshaw (2000) and Silke (2011) seriously challenge this pathological perception of the radical individual. As Crenshaw (2000) suggests, one of the common characteristics of radicals is their "normality". Radicalisation can be both intrapersonal (on the individual level) and interpersonal process (e.g. in the form of a radicalised group in our instance - Slovenskí branci, communities, subcultures, etc.).

Society as a whole can become radicalised, too. Radicalisation processes are complex and hard to predict, especially when young people are concerned. Academic approaches to radicalisation are based on a combination of two theories: frustration (relative deprivation theory) and contamination (exposure theory). The relative deprivation theory, proposed by Ted Gurr, is largely referred to as an efficient explanation of "why men rebel." According to Gurr (1970), when external conditions change (e.g., financial crisis, existential threat, or shaking of essential moral values in society) that do not match the individual's attitudes (expectations of conditions), a personal attitude (perception of relative deprivation) leads the individual to a political attitude (discontent), which in turn can lead to radicalism coupled with violent acts.

Khosrokhavar (2005), however, has shown that radicalisation cannot be directly and simply linked to expressions of frustration, preliminary indoctrination, political repression, or economic deprivation alone. As he points out, the research on radicalisation is mostly based on post factum justifications put forward by actors, which can be problematic as they are likely to fill the moral void that the actors experience. This focus on specific but limited individual reflections on radicalisation reinforces the individualistic and psychological orientation of current radicalisation researches towards a decontextualized perspective of individual's experience of the radicalisation process.

A simplistic view of the radicalisation process of young people can be summarized into several phases. It is important to bear in mind that it is neither a linear process, nor a causal one, when one phase conditions the emergence of the other, although this cannot be fully ruled out.

\section{From Passivity and Indifference to Revolt}

In a sense, contemporary society can be described as indifferent that have stripped all institutions, values and goals of their essence and content. The void and emptiness of contemporary society has been spreading in all spheres assuming the form of distrust. Science, power, work, the army, family, the church, political parties, and so on, have ceased to function as absolute and inviolable principles no one believes in them, no one puts anything into them anymore (Lipovetsky 2008). All this results in emotional emptiness, a comfort coupled with passivity and indifference in relation to social events, but also in distrust in everyone and everything. The research conducted by the Youth Council of Slovakia (2021) revealed that almost $62 \%$ of young people do not trust political parties.

Young people are very dissatisfied with the way political parties and politicians are (un)able to solve the problems they consider important. 68\% of 
young Slovaks think that elections are a waste of time. Trust in some public institutions is also very low. $61 \%$ of young people do not trust the courts; almost half of the young people do not trust the members of the National Council and the government of the Slovak Republic. Young people in Slovakia are also very distrustful and suspicious of other people. Up to $80 \%$ of young people are cautious when dealing with other people. Up to $54 \%$ think that their personal freedom must not be restricted even if it may put other people's health at risk. This is one of the factors that points to a disrupted social solidarity and a lack of understanding of one of the fundamental principles of a democratic society, namely the need to protect the weak and disadvantaged.

One phenomenon that is responsible for such condition in society is increased individualisation (even egoism) that can lead to disintegration of a young person in contemporary society. According to Durkheim (1973), disintegration is immanent to the ambivalence of individualisation processes. At the social structure level, it represents phenomena of social inequality. At the institutional level, it leads to declining rates of citizen participation in activities of individuals. At the social level, it is the absence of emotional support for young people. At the personal level, we see identity crisis and insufficient and inconsistent value education. An analytical interpretation of the concept of disintegration points to two subcategories, one of which is disorientation manifesting itself primarily in the realm of values and norms. A plurality of choices (even the contradictory ones) is one of the basic features of the individualisation process. Therefore, it is very likely to identify some symptoms of disorientation in terms of norms and their violation, or indecisiveness when it comes to commonly held values.

Disorientation encompasses an emotional aspect too, in particular the instability in social relationships caused by the pressure of competition and compelling the young people to be unique.

The second sub-category of disintegration is disorganization, which manifests itself in social differentiation that hinders integration in social relations and results in isolation of an individual, which promotes greater anonymity of young people's lives.

The process of disintegration in which both of the sub-categories merge poses serious problems linked with a certain degree of radicalisation - revolt. "Radicalisation, therefore, cannot be directly and simply linked to forms of frustration, preliminary indoctrination or to political repression or economic deprivation" (Khosrokhavar 2005). The process of disintegration must also be taken into account.

\section{From Revolt to Anger}

Disintegration leads to insecurity. Young people's insecurity can be anticipated in a number of life situations (Heitmeyer and Olk 1990):

- intractable situations, "the dead ends" in which they find themselves,

- unpredictability of life events and the demands placed upon them,

- uncertainty about their own status, e.g. in a family, a peer group, etc., 
- inconsistency of their own self-assessment and the expectations from others (parents, institutions, schools),

- inconsistency between own expectations, actual position and behaviour of important persons,

- absence of approval, not receiving any approval and understanding, or appreciation for something they believe is theirs,

- feeling helpless in terms of direction in life,

- when failure is seen as an expression of an unattainable goal, or when behaviour or performance does not match the expectations.

These insecurities lead to anger as the joint action of multiple external influences (social, economic and political) and their internal processing. Anger is thus not an automatic reaction to poverty and suffering, i.e., social problems. "Anger arises only where there is a reason to think that conditions could be changed, but are not. It is only when our sense of justice is offended that we react angrily, and this reaction by no means necessarily reflects personal injury" (Arendt 2004).

Self-radicalisation, which is related to the development of new communication technologies (especially the Internet and social networking sites), represents yet another form of a radicalisation mode. The use of new technologies for agitation and propaganda is an undeniable fact. However, their role and impact should not be overestimated. The advent of new media does not directly have the potential to bring about political or social change. Social actors make use of the communication tools they simply have at their disposal - it were newspapers, radio and television in the past, and today it is the Internet, social media, etc. Surely, new information and communication technologies have changed the ways in which extremists communicate, collaborate, and demonstrate their power. Violent action, however, is unlikely to originate from purely virtual ties (Cardon and Granjon 2010).

\section{From Anger to Aggression and Violence}

When there is a change in external conditions (e.g., financial crisis, existential threat, or shaking of essential moral values in society) that do not match the individual's attitudes (expectations of conditions), a personal attitude (perceptions of personal deprivation) leads the young person to a political attitude (discontent, anger), which in turn can lead to aggression coupled with acts of violence (Gurr 1970). Aggression in a form of aggressive behaviour commonly occurs in response to a real or only perceived threat. It manifests itself in obvious ways, at least as an attitude approving of violence against "the other", "the different", or "the unknown". "Violence arises from anger. To resort to violence in view of outrageous events or conditions is enormously tempting because of the immediacy and swiftness inherent in it. Under certain circumstances violence, which is to act without argument and without reckoning with consequences, is the only possibility of setting the scales of justice right again" (Arendt 2004).

Ondrejkovič (2000) states that violence perpetrated by youth can be considered a specific human behaviour, directed at enforcing the fulfilment of wishes, interests, 
laws, orders, etc., and is most often associated with power or domination. In the last decade, more and more young people have chosen the path of violence in their struggle for self-acceptance, recognition, promotion within a group or society or in their effort to gain a certain status. A contemporary society fosters individualisation process and that creates a constantly growing individual competition in the marketplace, which results in young people being forced to incorporate some violent elements of behaviour into their individual concepts and life plans.

The social success or effectiveness of such behaviour, i.e. the acquisition of more and more positive experiences with violence, especially in problem situations, contributes to the development of youth behaviour with an increasing number of violent elements. The logic behind youth violence is different, since a society "provides" youth violence with a certain platform in which it is tolerated. This includes rage that is rooted in exclusion of young people from the real social, political, cultural, and economic life. Alongside the expressive violence that is perceived as revolt, there is also the instrumental violence, which usually assumes the form of a delinquent strategy and delinquent career.

For Tilly (2003), a question as to why radicalisation occurs is not as important as a question of how radicalisation shifts towards extremism encompassing elements of violence. Extremist manifestations, attitudes, and actions represent a set of very diverse activities that generally take place in a public space, but can also be conspiratorial in nature. The activity of extremists covers a wide range of individual engagement activities, only some of which break the law. Extremists use a variety of instruments to achieve their goals, including modern communication and information technologies and modern propaganda techniques. It is this variability and heterogeneity of extremist actions and their actors that make it extremely hard to identify extremism (Vegrichtova 2017). Examining how someone becomes an extremist is much more interesting and important than knowing why one does so (Horgan 2008). Having knowledge of the agitation process (how does someone become an extremist) makes it possible to explore the following aspects:

- different incentives that motivate individuals to seek, accept or reject a particular ideology (the ideological basis of both radicalism and extremism are different ideologies that challenge democratic foundations of societies or some basic human rights and freedoms);

- particular roles, 'areas of agitation' that potential members assume;

- selection criteria, their characteristics and also objectives of the selection.

An "attitudinal affinity" with the goals of a particular group (a movement or even a political party) or a well-interconnected set of disagreements (complaints and protests) in line with their ideology can partially explain the agitation process. These purely individualistic explanations turn into reality only when agitation takes places in specific social and political contexts. In many ways, agitation in radical organisations is no different from agitation in mainstream organisations. From an organisational point of view, agitation is never a static process, but it is driven by the identified needs and expectations of an individual. All forms of 
agitation involve those who are engaged, committed (which is very characteristic of a certain segment of youth population) and reliable.

Any clandestine or legal organisation that seeks to attract new supporters will make use of both formal structures and informal networks and every communication channel open to them. There are numerous documented cases of the family environment and friendship networks that had an impact on recruitment to highrisk activism (transition from radicalism to extremism) (Della Porta 2013). A majority of young people becomes radicalised and turns to extremism when they come into a contact with active members of extremist groups through family or friendship routes and as a part of a micro-mobilisation context (Diani 2004). Their involvement and commitment deepens over time, although it does not happen in a logical, let alone a uniform way. The context, the method, and the personal characteristics of the future radicals differ. Media and news reports rightly claim that effective prevention of radicalisation should begin in the environment where agitation takes place.

\section{Slovak Conscripts}

One of the examples of radical groups in Slovakia and the most numerous in Slovakia is paramilitary organization Slovak conscripts (Slovenskí branci, SB), established in 2012. According to its website, Slovak conscripts is "military and physical-educational organization which, conducting military trainings, prepare itself for potential homeland defence. It is actively intervening and helping also in natural disasters such as floods and calamities" (Slovenskí branci 2021a). The organization, claiming itself as militia, brings mostly young people together and actually has approximately two hundred active members (Osvaldová 2018), but there are estimations about approx. two thousand people passed their trainings. (Macko 2020) Its Facebook fan page has more than 20,000 fans and almost 21,000 followers (as in April 2021). Just before the creation of Slovak conscripts, its founder Peter Svrček together with Michal Feling and Marek Rusyniak who studied in one of Russian universities (Hrammitino 2018), passed Russian Cossacks training of paramilitary organization Stjag which is part of patriotic organization Narodny sobor in Russia, supported by Russian orthodox church. After returning home, they established SB and two of Russian training graduates are still members of SB: Peter Svrček - commander of SB and Michal Feling one of SB instructors. (Mesežnikov - Bránik 2017, p. 22) SB is currently divided on territorial principle into 17 territorial units across Slovakia, resembling official armed forces or police. In addition, "Reserves of the Slovak conscripts" have been formed within SB in 2016, "which caters to members who cannot regularly attend the trainings" (Mesežnikov - Bránik 2017, p. 21). SB activities include trainings such as physical, topographic, medical, tactical, firearm and engineering training. They even conduct regular exercises (Slovenskí branci 2021b) and assist with environmental issues, e.g., cleaning after floods, picking up the trash (Mesežnikov - Bránik 2017, p. 22).

However, functioning and activities of Slovak conscripts constitutes a security threat for the society and the state. This is based on the fact that SB is not backed 
up by any Slovak law and it operates in parallel with official state armed forces. Hence, that undermines the very essence of being a state based on "monopoly on legal and legitimate use of physical force..." (Paulička 2002, p. 430) State monopoly on violence is "concept that the state alone has the right to use or authorize the use of physical force. It is widely regarded as a defining characteristic of the modern state" (Britannica 2021). As concluded Pavel Macko, retired Slovak general, former highest positioned representative of the Slovak Armed forces within the NATO and former deputy chief of the General staff of Slovak Armed forces, "they are not backed up by law... Militia called Slovak conscripts does not exist. It has no authorization to act, which means that it is just group of citizens proclaiming themselves to be authorized group... empowered to act as security service which is reserved exclusively for the state" (Macko 2020). Next reason of considering SB as a security threat is fact that its leading persons express their xenophobic attitudes, which poses a risk to adolescents who are the most of SB's members (Jursa 2014, Gebert 2018). In addition, Slovak conscripts "after long period of support and cooperation" appointed Tibor Eliot Rostas, editor-in-chief of Slovak conspiracy magazine Zem\&Vek [Earth\&Age] who has been sentenced for anti-Semitic article, as "supreme command member of militia forces of Slovak conscripts" (Zem\&Vek 2020). Every year since 2017, Slovak conscripts are subject of every annual report of Slovak information service which is one of two Slovak secret services (Slovenská informačná služba 2020). Since Slovak conscripts attract young people interested in military, they are also competitors of official army recruitment programs - Voluntary military training and Active reserves. In addition, they are questioning these army programs on their website (Slovenskí branci 2019a) and Facebook fan page (Slovenskí branci 2019b).

Although love and commitment to Slovakia is considered as the supreme value, SB puts an emphasis also on Slavic mutuality, as reflected e.g., in their recent Facebook post from 11 April 2021 in the context of actual increasing tension in the area of Ukrainian-Russian borders, stating that "We refuse to take part in inflammatory campaign against Russia and everything Slavic, similar to one from the time of Third Reich. We shall not take arms against Russian brothers and other brotherly nations" (Slovenskí branci 2021c). SB's affiliation with Russia indicates also fact that Slovak conscripts conducted training in the property of Jozef Hambálek - founder of Slovak branch of Russian motorcycle club Night wolves, which openly supports Putin's regime. As written by Slovak nongovernmental security think-tank Globsec, since such group is not organized or controlled by the state, there is serious risk that "foreign state actors including secret services could, naturally, focus their attention on such groups, which shares many ideological and geopolitical attitudes with them" (Kupková and Milo 2019, p. 5). 


\section{Methodology}

The research aimed to describe and analyse the character of a radical and nonradical teenager in Slovakia and identify the sources and forms of radicalisation. As a research method, we utilized a qualitative probe among young people aged 14-17 adopting the life story approach. Data were gathered using semi-structured dyadic and individual interviews. We carried out thirteen dyads (the average length of the interview was 90 minutes) and sixteen individual interviews (the average length of the interview was 60 minutes). The first research sample comprised 16 respondents - radical teenagers (in various stages of radicalisation) of different ages, from different socio-economic backgrounds and types of schools residing in six different self-governing regions. Only the teenagers who would consider voting for a radical party if he or she were to go to polls were included. The second sample group (created for comparison purposes) comprised 26 young non-radical teenagers (many of them with ingrained prejudices and xenophobic attitudes towards minorities). They were of different ages and genders, came from different socio-economic backgrounds, studied in different types of schools, and resided in villages and towns across Slovakia. Only the teenagers who would not consider voting for a radical party if he or she were to go to polls were included in the sample group.

\section{Results}

Radical teenagers live in all regions of Slovakia, in both towns and villages; they come from different family backgrounds and types of schools. They differ in the degree of radicalisation. They are boys and girls of different nationalities and they have reported that "even" young Roma are organized in some radical groups. There is no visible difference between them and their non-radical peers. They all dress similarly. At school, they differ from their classmates in being either noncommunicative or, on the other hand, more interested in discussing the issues pertaining to the recent Slovak history and the current affairs. To most of the topics they have prepared answers (they believe in them and will not allow any other alternatives), which they obtained mostly from their families or from the radical groups that are active in Slovakia (personal attendance of their gatherings, videos shared on social media).

They have no limits of self-criticism. They want to belong somewhere, since they belong nowhere (no family background, their immediate environment does not accept them, causes their suffering and exposes them to problems they cannot deal with) or they belong where they do not really want to. They want to be different and have an unfulfilled desire for discipline and order from their family environment. They seek a sense of security in an uncertain world of freedom and democracy. They often have problems (mental, social, family, etc.) they cannot solve or have failed at solving it. They have problems at school associated with learning, motivation, relationships, and a poor quality of the school they attend. 
The research findings revealed that young teenagers are amongst the priority target groups of radical political subjects, organizations, and individuals. There are several reasons as to why young people fall prey to them: from frustration with the current social and "political" system in Slovakia often linked with ignorance of history, through the "supportive" family background, the ongoing state policy aimed at solving the problems of a certain segment of the Roma minority, to copying negative sentiments towards migrants in society. Every radical individual processes these individual motives or their combination internally and does so with a varied intensity.

One of the main sources of radicalisation of young people is their family background. What we have in mind is: a compatible pattern of parents, grandparents and older siblings; family problems (disintegration, reconstruction, and dysfunction); the social status of families and value orientations of their members. Both direct and indirect impacts of family on radicalisation of a young teenager were recorded. The teenagers are influenced directly by their parents, one of them or their siblings who themselves are supporters or sympathisers of a radical group. The family indirectly contributes to radicalisation of a teenager when parents do not provide their child with the harmonious equilibrium and balance in life in terms of sustainability and potential for creating valuable family, interpersonal relationships, conditions for education, social security, and preparation for a dignified life and life choices (Table 1).

Table 1. Direct and Indirect Influence of the Family on the Radicalization

\begin{tabular}{|l|l|}
\hline \multicolumn{1}{|c|}{ Direct } & \multicolumn{1}{|c|}{ Indirect } \\
\hline $\begin{array}{l}\text { The parent profoundly influences the } \\
\text { formation of socio-political opinions of } \\
\text { their children - teenagers. Following the }\end{array}$ & $\begin{array}{l}\text { Teenagers have a close relationship with } \\
\text { grandparents, who are oftentimes their co- } \\
\text { educators (as a result of family dissolution } \\
\text { parent's example, teenagers lean towards } \\
\text { radical solutions to the socio-political } \\
\text { situation in society (not in a form of } \\
\text { visit them, stang over for the weekend and } \\
\text { typical teenage revolt and resistance to } \\
\text { alder authorities). Teenagers who have no } \\
\text { their permanent residence and control of } \\
\text { their parent (s). Clearly, grandparents } \\
\text { other important and trustworthy institution } \\
\text { sesides their families such as friends and } \\
\text { teachers with different political beliefs and }\end{array}$ \\
$\begin{array}{l}\text { of better life under the communist } \\
\text { value orientations are "programmed" to } \\
\text { join radical groups and become more } \\
\text { drawbacks of that regime). Such teenagers } \\
\text { then claim that socialism provided } \\
\text { radicalized with time. }\end{array}$ & $\begin{array}{l}\text { everyone with the proclaimed social } \\
\text { equality and obligation to work. }\end{array}$ \\
\hline $\begin{array}{l}\text { Parents of young radicals have different } \\
\text { professional orientations, but they are } \\
\text { mainly entrepreneurs, state employees in } \\
\text { the security forces (police/army); some }\end{array}$ & $\begin{array}{l}\text { Teenagers might also grow up in families } \\
\text { with authoritarian parents and experience } \\
\text { associate themselves with communities } \\
\text { that have to do with weapons, cars or } \\
\text { motorcycles. }\end{array}$ \\
\hline
\end{tabular}




\begin{tabular}{|l|l|}
\hline $\begin{array}{l}\text { Teenagers are oftentimes under the } \\
\text { influence of older radicalized siblings, they } \\
\text { look up to them, they seek the company of } \\
\text { young people that are older than them; they } \\
\text { mirror their behaviours and adopt their } \\
\text { opinions without a deeper understanding of } \\
\text { the matter and the consequences. }\end{array}$ & $\begin{array}{l}\text { Families of radical teenagers might also } \\
\text { have a family member who is disabled or } \\
\text { seriously ill and who requires extra care } \\
\text { special care. }\end{array}$ \\
\hline $\begin{array}{l}\text { Siblings have a close relationship with an } \\
\text { authoritarian worldview. }\end{array}$ & $\begin{array}{l}\text { Teenagers often live in incomplete, broken } \\
\text { families (without one biological parent), in } \\
\text { blended, reconstructed families with a } \\
\text { stepparent, and even with grandparents } \\
\text { and step-siblings. }\end{array}$ \\
\hline & $\begin{array}{l}\text { Upon dissolution of the original family } \\
\text { unit, teenagers often move to a new place } \\
\text { (village or town), they had to adapt to a } \\
\text { new environment and establish new } \\
\text { relationships. }\end{array}$ \\
\hline $\begin{array}{l}\text { Parents of radical teenagers are often } \\
\text { people with lower level of education, } \\
\text { working class or farmers who lead "the } \\
\text { simple people" lifestyle, or are in or on the } \\
\text { verge of poverty. }\end{array}$ \\
\hline
\end{tabular}

The critical state of society and problematic functioning of the state structures in Slovakia together with the overall social "climate" and immorality is a breeding ground for youth radicalisation. Teenagers are very perceptive of this situation, respond vigorously and revolt against it and/or want to remedy the situation in a radical manner. Teenagers are particularly frustrated with the unresolved issues in society (Table 2).

Table 2. The Influence of Society on the Radicalization (Expressions of Young Radicals)

\begin{tabular}{|c|c|c|}
\hline The State of Society & $\begin{array}{l}\text { The Functioning of the } \\
\text { State }\end{array}$ & Social Climate \\
\hline $\begin{array}{l}\text { They are critical of } \\
\text { injustice and the great } \\
\text { social disparities between } \\
\text { individual people, groups } \\
\text { of people, regions and } \\
\text { countries. }\end{array}$ & $\begin{array}{l}\text { They do not trust anyone } \\
\text { who is currently in power. }\end{array}$ & $\begin{array}{l}\text { They dislike chaos and } \\
\text { morals (?) in society } \\
\text { (mess, dirt, decay, } \\
\text { parasitizing). }\end{array}$ \\
\hline $\begin{array}{l}\text { They do not trust the } \\
\text { system of parliamentary } \\
\text { democracy, they do not } \\
\text { believe that state } \\
\text { administration or any } \\
\text { political party truly address } \\
\text { problems that Slovakia } \\
\text { faces. }\end{array}$ & $\begin{array}{l}\text { They condemn corruption - } \\
\text { in general terms, and } \\
\text { criticize all politicians, } \\
\text { primarily those from the } \\
\text { ruling government party; } \\
\text { they pay close attention to } \\
\text { corruption in distribution/ } \\
\text { embezzlement of the EU } \\
\text { funds. }\end{array}$ & \\
\hline
\end{tabular}




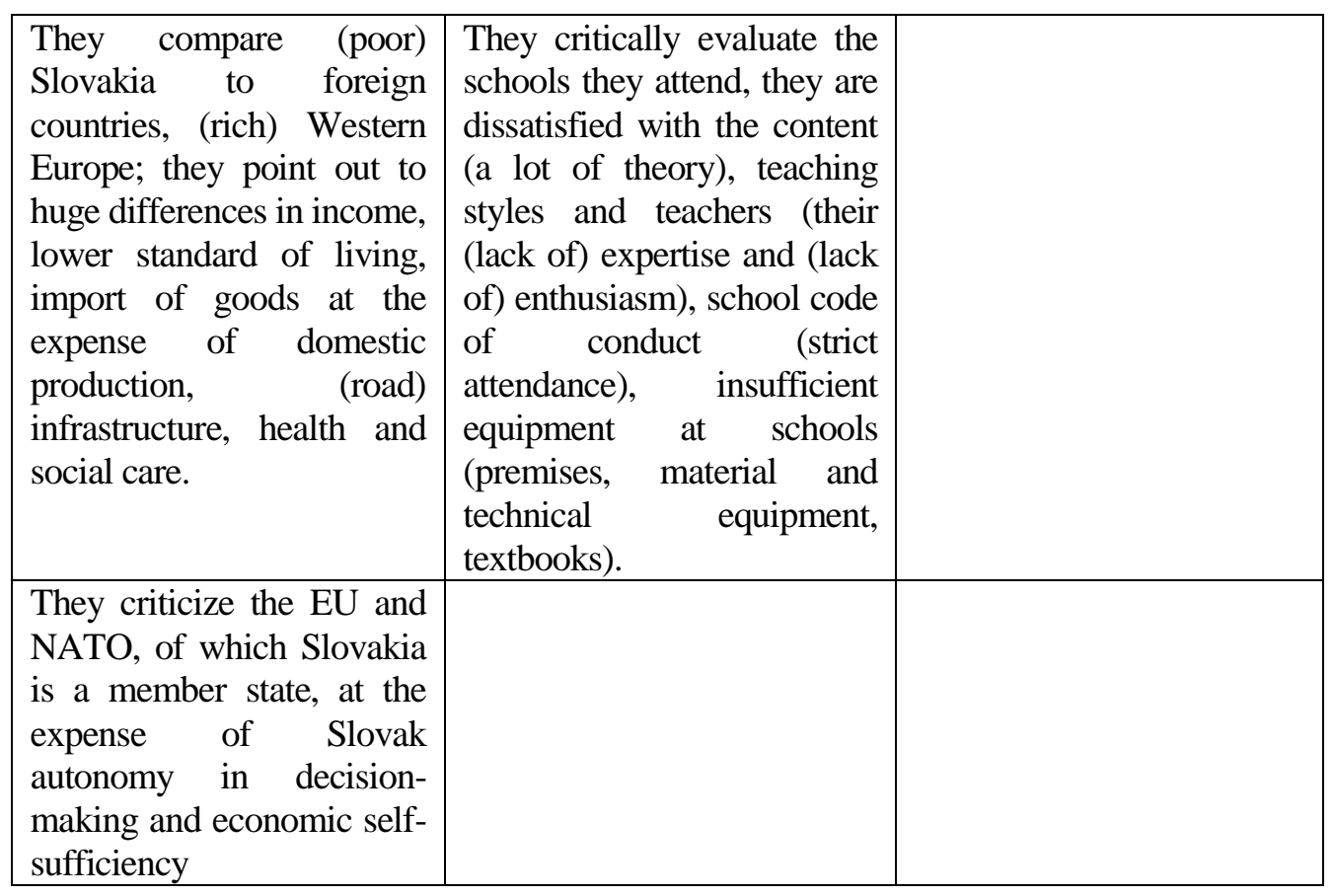

One of groups that are targeted by radical teenagers is the Roma minority, against which they wage an "imaginary" but (unfortunately) sometimes also a real-life war. For radical teenagers the Roma represent the enemies in a system that is not working well and need to be changed. Slovakia is a home for both the majority and the Roma minority. For one of these segments of population, however, it is difficult to integrate into society while the other has problems accepting them.

The only experience of many of the radical teenagers with migrants/ immigrants to Europe was that presented in the media. In spite of that, the ideological argumentation of many is saturated with the topic of migration. They perceive migrants as a threat to Slovakia and it undermines the sense of solidarity even among the non-radical teenagers. Teenagers link the arrival of migrants to Europe, and possibly also to Slovakia with a number of potential problems (Table $3)$.

Table 3. Roma and Migrants as a Source of the Radicalization (Expressions of Young Radicals)

\begin{tabular}{|c|c|}
\hline Roma People & Migrants \\
\hline $\begin{array}{l}\text { They are angry with the maladjusted } \\
\text { Roma people who: make life } \\
\text { uncomfortable for them or their families, } \\
\text { neighbours and even the unknown fellow } \\
\text { citizens; pose threat to their property; } \\
\text { verbally assault or physically attack them; } \\
\text { for some teenagers these experiences have } \\
\text { led to undisguised hatred towards the } \\
\text { Roma; some of the teenagers are even } \\
\text { scared of the Roma people. }\end{array}$ & $\begin{array}{l}\text { They see chaos, destabilization and disorder } \\
\text { in the coastal European countries through } \\
\text { which migrants enter the mainland. }\end{array}$ \\
\hline
\end{tabular}




\begin{tabular}{|l|l|}
\hline $\begin{array}{l}\text { They are angry with the double standard } \\
\text { ("positive discrimination") that is applied } \\
\text { - "the whites" and the Roma, who are } \\
\text { better off in terms of their place in the } \\
\text { social system, a specific place in a village } \\
\text { or town, the life with some "privileges" in } \\
\text { school. }\end{array}$ & $\begin{array}{l}\text { Shival of large numbers of migrants to } \\
\text { migrants being in their neighbourhoods. }\end{array}$ \\
\hline $\begin{array}{l}\text { They have a (mostly) negative experience } \\
\text { from the encounters and coexistence with } \\
\text { the Roma people, when the Roma are } \\
\text { hostile, aggressive, but also } \\
\text { loud/dirty/intrusive, they make a mess, } \\
\text { they are always in separate groups, they } \\
\text { isolate themselves at school, etc. }\end{array}$ & $\begin{array}{l}\text { They believe that migrants pose a security } \\
\text { threat to Slovakia, since ISIS terrorists often } \\
\text { infiltrate themselves among the groups of }\end{array}$ \\
\hline $\begin{array}{l}\text { They criticise unemployment of Roma } \\
\text { people, saying that they mostly do not } \\
\text { want to work. }\end{array}$ & $\begin{array}{l}\text { They believe that migrants pose a security } \\
\text { threat to Slovakia, since ISIS terrorists often } \\
\text { infiltrate themselves among the groups of } \\
\text { migrants. }\end{array}$ \\
\hline $\begin{array}{l}\text { They heard about or were even victims of } \\
\text { a crime committed by the Roma, e.g., } \\
\text { when they steal, vandalise, deal drugs, rob } \\
\text { people. }\end{array}$ & $\begin{array}{l}\text { They believe conspiracy theories claiming } \\
\text { that migration is controlled "from the } \\
\text { higher places". }\end{array}$ \\
\hline $\begin{array}{l}\text { They regard the Roma as irresponsible } \\
\text { parents who bear offspring whilst being } \\
\text { unable to care and provide for themselves, } \\
\text { they do not take care of their children, } \\
\text { who then do drugs..., skip school or are } \\
\text { not prepared for school. }\end{array}$ & $\begin{array}{l}\text { They think that the reports of mainstream } \\
\text { media on migration cannot be trusted. } \\
\text { Young people think that migrants do not } \\
\text { want to stay in Slovakia and they would } \\
\text { find it difficult to get used to living here. }\end{array}$ \\
\hline $\begin{array}{l}\text { They are annoyed with the fact that no one } \\
\text { addresses these problems and nothing } \\
\text { changes for the better. }\end{array}$ & $\begin{array}{l}\text { They understand the motivations of war } \\
\text { refugees, but have decided to listen to and } \\
\text { believe those who claim that there are } \\
\text { socio-economic reasons for migrants } \\
\text { settling in Europe. }\end{array}$ \\
\hline
\end{tabular}

Teenagers susceptible to radicalisation seek a way out of the problems of society posed to them by an extremist politician, a former teacher - a man of the people who speaks clearly, boldly and "without beating about the bush", someone who has already taken care of them and their families, defended their interests ("rights") and who, as they say, would deal with the Roma. That someone also offers them a place in their youth fraction of their political party. Additionally, their party network has functional informal structures in which a young confused person acquires ideological beliefs, establishes friendships (with "smarter older" people), finds personal protection, and maybe money too. Most of all, such a teenager finds much needed support (both financial and emotional) there. 
Differences in Perception among Radical and Non-Radical Teenagers in Particular Areas of Life in Slovakia

$\underline{\text { Slovakia as a Country }}$

Non-radical teenagers hold mostly a positive view of Slovakia, in terms of its nature, history, and culture. They also speak well of people and interpersonal relationships. When radical teenagers talk about Slovakia, they mostly refer to its cultural and historical sights and natural wonders.

\section{$\underline{\text { Regional Differences }}$}

Both groups see that there are great socio-economic disparities between the regions. Radical teenagers talk about a significantly higher quality of life in western Slovakia. Both groups are aware that a city offers more opportunities (and a higher quality of life) in comparison to the country. Radical teenagers reported to have stronger ties to the country and smaller towns.

\section{$\underline{\text { Social Differences }}$}

Radical teenagers are bound by the same idea - equality. They demand a change of the current social and political system. Non-radical teenagers perceive social differences to a much lesser extent and they are more likely to seek new opportunities of becoming actively involved in helping the social and other minorities, including the poor. They hardly ever consider the change of the social system.

\section{Under Communism}

The call for socialism - the idea of equality and prosperity for all and communism - but without taking into account any of the negative phenomena associated with the regime - is prevalent mainly in statements of radical teenagers.

\section{The World}

Both groups worry about terrorism in the global world. These worries, however, do not stand in the way of their plans to travel, or even work or live abroad. It is hard to assess members of which group have a stronger desire to return and live in Slovakia again.

Roma

Radical teenagers present a strongly negative attitude towards the Roma, which, however, does not always correspond with their own personal experience. On the contrary, if a non-radical teenager holds a negative attitude or prejudices towards the Roma people it is because of his or her negative personal experience. Non-radical teenagers view the differences between the majority and the Roma more sensitively and talk more often about the need to help them. On the other hand, radical teenagers tend to generalize more often and (some) promote (exclusively) radical solutions to problems associated with the Roma minority.

\section{Food Self-Sufficiency}


Radical teenagers repeat the learned phrases about their vision of Slovakia that one day will grow local produce again...and will rebuild "sugar factories and breweries". Non-radical teenagers do not focus on this topic at all unless prompted.

\section{Slovak History}

Non-radical teenagers do not show a great interest in history (of Slovakia), so they tend to be ignorant when it comes to it or present different levels of knowledge acquired at school. Radical teenagers, on the other hand, tend to explain the historical events of Slovakia during the World War II according to allegedly uncensored sources that are mostly inconsistent with the established scientific interpretation. In addition, they do so without making any effort to seek the truth, or without any broader discussion in other than a party or radicalized environment.

\section{Solidarity}

Many of the non-radical teenagers either do not feel the need for solidarity or do not articulate it, and therefore do not get involved. Those non-radical teenagers who express the need for solidarity advocate help or support for all who need it, not just the selected groups. Radical teenagers more often distinguish between people who deserve help and those who do not. Solidarity with the Roma population is out of the question for radicals with a higher degree of activism.

\section{$\underline{\text { Seniors }}$}

On the one hand, radical teenagers take on the role of lobbyists who promote the increase of pensions for senior citizens. On the other hand, they blame seniors for their persistent electoral support for the ruling party. Some radical teenagers even talk about the upper age limit for senior voters. Non-radical teenagers tend to perceive the status of seniors in society as unproblematic, especially of those who had been well-situated during their active lives or those who are still actively working.

\section{Media - Information}

Most teenagers do not trust the mainstream media. Both groups relativize information from the Internet. For non-radicals the people from their family, school, or interest groups seem to be the trustworthy sources, whereas radicals mostly trust people from the radical group to which they belong (primarily the young people who are older than them), or family members with similar mentality and way of thinking.

\section{$\underline{\text { Politicians }}$}

All radical teenagers have no trust in politicians in Slovakia, especially then those in the current government. They also do not trust the majority of politicians in the parliament. They deem them corrupt, 'recycled' and without charisma. For non-radicals, the president of the Slovak Republic seems to be the most popular. $\underline{\text { Migrants }}$ 
Radical teenagers fear possible terrorism, economic disruption of the country and an increase in crime. They base their opinions on information reproduced within their group, and on their sources shared on social media sites. Non-radical teenagers are mainly concerned with migrants taking up the low-income jobs. They also worry about migrants bringing economic, cultural and security instability to Slovakia. Nevertheless, they also share positive attitude towards them.

\section{Corruption}

"The system in Slovakia is rotten" (read: corrupted) is a typical phrase of a radical. Corruption is rife especially in top politics. Non-radicals do not go into a debate about corruption, which is a symptom of estrangement of an average teenager from the wider community.

\section{Concerns - Fear}

Radical teenagers formulate their worries about Slovakia, they comment on the world events, their fear war, and share different conspiracy theories about the world governance and the persecution of those who know the "truth". Other radicals would say that they are not afraid of anything, but are (very) sceptical and perceive the world very negatively. Non-radicals worry more about issues related to their age. Their worries concern the near future, successful completion of their education, finding a job or a partner of their dreams. They are able to say what they can do to dispel their fears and uncertainties. Nevertheless, similarly to radical teenagers, they assume that a change for the better in Slovakia is not a matter of the foreseeable future.

\section{Conclusions}

The common denominator of radical teenagers in Slovakia is the need and desire to belong somewhere. Security is what they lack in their lives. They are searching for the haven of security, prosperity, hope and the sanctified violence. The reasons behind their not belonging anywhere should be sought in families, schools, among peers, in communities and in society as such. It is there where we need to search for that exact moment when the child has "disconnected" from the guidelines on his or her path to a desired way of thinking about justice, humanity and the truth.

"Social injustice" is yet another domain that shapes the Slovak radical teenager. It evokes anger and frustration that is gradually growing. Outside their homes, they encounter yet another burden for their "radical" mind - the system which, as they see (encouraged by the others) does not function in the same way for everyone; it does not favour those who have little and have worries that others cannot even imagine.

Radical teenagers come from a specific family background, where the word 'discipline' is the basis for the family functioning. The family thus becomes a place for radicalism or escape. There is no doubt that the mind of a teenager 
becomes "infected" with radicalism where it is commonly presented. Elsewhere, a teenager seeks radical group as an escape from families that are tormented by serious relational problems, health issues of a family member, difficult socioeconomic situation, and unfulfilled life expectations. This all presents one vicious circle from which a young person wishes to escape.

Radical teenagers cannot truly "progress" at home or at school. Many have already got burnt for presenting their opinions and they want to achieve more and want to do something big in their lives. So, with or without support they dare to look around and find others in the same situation and with the same mindset. Many have found AUTHORITY in the form of a leader/commander who shows them the right path...

\section{Acknowledgments}

Our thanks to the project Foreign Students' Education with an Emphasis on Creating Key Competences in the Context of Building a Working Career and the Inclusion into the Labour Market in Slovakia. Project num. 049TUKE-4/2019.

\section{References}

Arendtová H (2004) O násilí. (About violence). Praha: OIKOYMENH.

Britannica (2021) State monopoly on violence. Retrieved from https://www.britannica. com/topic/state-monopoly-on-violence. [Accessed 12 April 2021]

Cardon D, Granjon F (2010) Mediactivistes. Paris: Presses de Sciences-Po.

Crenshaw M (2000) The psychology of terrorism: an agenda for the 21st century. Political Psychology 21(2): 405-420.

Della Porta D (2013) Clandestine political violence. Cambridge: Cambridge University Press.

Diani M (2004) Networks and participation. Malden, MA: Blackwell Publishing.

Durkheim E (1973) Der Selbsmord. (The self-death). Darmstadt: Luchterhand.

Gebert J (2018) Až prijje válka. (When the war comes). Documentary film. Czechia, Croatia.

Gurr T (1970) Why men rebel. Princeton: Princeton University Press.

Heitmeyer W, Olk T (1990) Individualisierung von Jugend. (Individualization of youth). Munchen: Juventa.

Horgan J (2008) From profiles to pathways and roots to routes: perspectives from psychology on radicalization into terrorism. The Annals of the American Academy of Political and Social Science 618(1): 80-940.

Hrammitino (2018) Славянские Сборы В Рождествено (Slavic assembly in Christmas). Retrieved from: http://hrammitino.ru/?p=2152. [Accessed 10 April 2021]

IUVENTA (2013) Ako vidiš extrémistov Ty? (How do you see extremists?) Bratislava.

Jursa D (2014) Toto nie je hra. (This is not a game). Documentary film. Slovakia.

Khosrokhavar F (2005) Suicide bombers: Allah's new Martyrs. London: Pluto Press.

Kupková I, Milo D (2019) Hybridné hrozby na Slovensku - Polovojenské a extrémistické skupiny - Analýza legislatívy, štruktúr a procesov. (Hybrid threats in Slovakia Paramilitary and extremist groups - Analysis of legislation, structures and processes). Bratislava: Globsec. 
Lipovetsky G (2008) Éra prázdnooty. Úvahy o současném individualizmu. (The era of emptiness. Reflections on contemporary individualism). Praha: Prostor.

Macko P (2020) Prečo sú pre nás Slovenskí branci hrozbou? (Why are Slovak defenders a threat to us?) In Týždeň. Retrieved from: https://www.tyzden.sk/politika/61310/bliz ni-su-pre-nas-slovenski-branci-hrozbou-/ [Accessed 12 April 2021]

Mesežnikov G, Gyárfášová O (2016) Súčasný pravicový extrémizmus a ultranacionalizmus na Slovensku. Stav, trendy, podpora. (Contemporary right-wing extremism and ultranationalism in Slovakia. Status, trends, support). Bratislava: IVO.

Mesežnikov G, Bránik R (2017) Hatred, violence and comprehensive military training. The violent radicalisation and Kremlin connections of Slovak paramilitary, extremist and neo-Nazi groups. Budapest: Political Capital.

Ondrejkovič P (2000) Násilie ako sociálnopatologický jav. (Violence as a sociopathological phenomenon). Filozofia 55(1): 27-35.

Osvaldová L (2018) Gajdoš a šéf armády prepustia vojakov, ktorí sú u Slovenských brancov. (Gajdoš and the head of the army will release the soldiers who are with the Slovak conscripts). Retrieved from: https://dennikn.sk/1195860/gajdos-a-sef-armadyprepustia-vojakov-ktori-su-u-slovenskych-brancov/ [Accessed 14 April 2021]

Paulička I (Ed.) (2002) Všeobecný encyklopedický slovník, $S$ - Ž. (General encyclopedic dictionary, S - Ž). Praha: Ottovo Nakladatelství.

Štefančík S, Macháček L, Poláková E, Spálová L, Kluknavská A, Bieliková M, et al. (2013) Ludovít Šrámek Pravicový extrémizmus a mládež na Slovensku. (Rightwing extremism and youth in Slovakia). Tribun: EU Brno.

Rada mládeže Slovensko (2021) Hodnoty mladých - veria mladí v demokraciu? (Values of young people - Do young people believe in democracy?) Retrieved from: https:// mladez.sk/2021/01/31/hodnoty-mladych-veria-mladi-v-demokraciu/ [Accessed 10 April 2021].

Silke A (2011) The psychology of counter-terrorism. London: Routledge.

Slovenská informačná služba (2020) Správy o činnosti SIS. (SIS activity reports). Retrieved from: https://www.sis.gov.sk/pre-vas/sprava-o-cinnosti.html [Accessed 17 April 2021]

Slovenskí branci (2019a) Slovenskí branci vs. DVP OS SR. Retrieved from: http://www. slovenski-branci.sk/slovenski-branci-vs-dvp-os-sr/ [Accessed 30 November 2019]

Slovenskí branci (2019b) Kde boli Aktívne zálohy počas kalamity alebo ako bol za milióny vytvorený projekt, ktorý nefunguje... (Where there were active backups during the calamity or how a project was created for millions that does not work...) In Slovenskí Branci Facebook Fan Page. Retrieved from: https://www.facebook.com/slovenski branci1/posts/2211149539140992/ [Accessed 14 April 2021].

Slovenskí branci (2021a) Úvod. (Introduction). Retrieved from: https://slovenski-branci.es tranky.sk/ [Accessed 15 April 2021]

Slovenskí branci (2021b) Slovenskí branci channel. In Youtube. Retrieved from: https:// www.youtube.com/channel/UCIH3q1epHn4RQ6RZyfYEMjw [Accessed 15 April 2021]

Slovenskí branci (2021c) Za mier! (For peace!) In Slovenskí Branci Facebook Fan Page. Retrieved from: https://www.facebook.com/slovenskibranci1/posts/2841777502744 856 [Accessed 16 April 2021]

Smolík J (2020) Psychologie terorismu a radikalizace: Jak se z beránku stávají vlci. (The psychology of terrorism and radicalization: how a lamb becomes wolves). Brno: Mendelova Univerzita v Brně.

Smolík J, Vejvodová P (2010) Politický extremismus jako bezpečnostní hrozba? (Political extremism as a security threat?) In Vybrané bezpečnostni hrozby a rizika 21. století. Brno: MU.

Tilly C (2003) The politics of collective violence. Cambridge: Cambridge University Press. 
Vol. 9, No. 2 Brutovská \& Béreš: How do Revolting Young People Become Radicals...

Vegrichová B (2017) Extremismus a společnost. (Extremism and society). Plzeň: Aleš Čeněk.

Zem\&Vek (2020) T. E. Rostas v najvyššom veleni domobrany SB. (T. E. Rostas in the Supreme Command of the SB militia). Retrieved from: https://zemavek.sk/t-e-rostasv-najvyssom-veleni-domobrany-sb/ [Accessed 17 April 2021] 